Cahiers de recherches médiévales

\title{
Maternity and Chivalry after Chrétien
}

The Case of King Lot's Wife

\section{Peggy McCracken}

\section{(2) OpenEdition \\ Journals}

Electronic version

URL: https://journals.openedition.org/crm/2655

DOI: $10.4000 / \mathrm{crm} .2655$

ISSN: 1955-2424

Publisher

Honoré Champion

\section{Printed version}

Date of publication: 15 December 2007

Number of pages: $75-85$

ISSN: 1272-9752

\section{Electronic reference}

Peggy McCracken, "Maternity and Chivalry after Chrétien", Cahiers de recherches médiévales [Online],

14 | 2007, Online since 15 December 2010, connection on 15 December 2022. URL: http:// journals.openedition.org/crm/2655 ; DOI: https://doi.org/10.4000/crm.2655 


\section{RM}

\section{Maternity and Chivalry after Chrétien : The Case of King Lot's Wife}

In Le Conte du graal Chrétien de Troyes famously introduces a tension between a mother's desire to keep her son from chivalry and the son's desire to be a knight. Perceval's mother's effort to hide all knowledge of knights and their pursuits from her son is an attempt to keep him from a chivalric destiny scripted by his father's lineage and her own ${ }^{1}$. This mother's effort to protect her son from the fate of his father and brothers is thwarted when Perceval encounters knights passing through his mother's lands, immediately wishes to be like them, and rides away to be knighted at Arthur's court, setting out on a course that will leave his mother behind. As a new knight, Perceval learns to distance himself from his mother's lessons, even as he seeks to return to her lands 2 .

Mothers have a new importance in Chrétien's last romance, as Matilda Bruckner has noted. They may appear in the earlier romances, but their presence or absence makes little difference to the other characters or to the story ${ }^{3}$. Bruckner argues that Le conte du graal and its continuations identify mothers - both their metaphorical and literal presence and absence - as an enigma that continues to invite questions and rewritings. The appearances of Gauvain's mother in Arthurian romances after Chrétien offers a focus for some of those questions.

\section{The Wife of King Lot}

Although Gauvain's mother is not portrayed as directly in relation to her son's chivalric formation as is Perceval's, she too appears in Le conte du graal. Isolated in the enchanted Castle of Ladies along with Arthur's mother, five hundred squires, many damsels and disinherited widows, she waits for a knight who will end the castle's enchantments and integrate its inhabitants into the outside world while he abandons that world himself. This knight will hold the castle, he will knight the young men, marry the ladies to suitable knights, and restore the older women to their lands. The queens and their attendants probably wait in vain, a boatman explains to Gauvain, since they are unlikely to find such a great knight who will be willing to remain in the castle :

Mais ainz ert mers trestote glace

Que 1'en un tel chevalier truisse

\footnotetext{
${ }^{1}$ "Chevaliers estre deüssiez » Le conte du graal, éd. W. Roach, Geneva, Droz, 1959, v. 412.

${ }^{2} \ll$ Or ne dites jamais, biax frere,

Fait li preudom, que vostre mere

Vous ait apris rien, se je non. » (Conte du graal, éd. cit., v. 1675-77)

3 «Rewriting Chrétien's Conte du graal-Mothers and Sons : Questions, Contradictions, and Connections ", The Medieval Opus : Imitation, Rewriting, and Transmission in the French Tradition, éd. D. Kelly, Amsterdam, Rodopi, 1996, p. 214.
}

Cahiers de Recherches Médiévales, 14, 2007 
Qui el palais remanoir puisse,

Qu'il le covenroit a devise

Bel et sage, sanz covoitise,

Preu et hardi, franc et loial,

Sanz vilonie et sanz tot mal.

S'uns teus en i pooit venir,

Cil porroit le chastel tenir;

Cil rendroit [as dames] lor terres

Et feroit pais des morteus guerres,

Les puceles marïeroit

Et les vallés adouberoit

Et osteroit sanz nul relais

Les enchantemens del palais. ${ }^{4}$

Gauvain arrives at the castle and proves to be the awaited champion, putting an end to the enchantments that have isolated the domain. Although the custom of the castle dictates that Gauvain may now never leave, he says that he could not stay for even seven days without coming and going as he likes (v. 8028-32). When he meets his mother and his mother's mother, the elder queen repeats the injunction: if Gauvain does not wish to do them wrong, he will never leave the castle. Gauvain protests, and the queen agrees that he may leave if he will return before nightfall. She further agrees that she will not ask his name for seven days (v. 8332-53).

Gauvain leaves the castle and he does return, but we never learn whether he will stay and hold the castle or leave to seek further adventures. Chrétien's unfinished romance leaves Gauvain in the realm of his mother awaiting King Arthur's arrival to witness his battle with Giromelant. In other words, Chrétien leaves Gauvain in isolation with his mother, precisely the place from which Perceval left to seek adventures at the beginning of the romances.

Chrétien's unfinished Le Conte du graal inspired a number of continuations ${ }^{6}$. Thirteenth-century writers continued the adventures of Gauvain and Perceval and elaborated long stories about King Arthur's court and the grail, but they pay little attention to mothers. It is as though writers after Chrétien seek to avoid the perilous return to the mother represented in Le Conte du graal: knights leave their mothers behind once they are knighted, and mothers disappear from their stories. Gauvain's mother is a curious and persistent exception - she keeps reappearing in her sons' stories in thirteenth-century romances. In the Perlesvaus she abandons her infant son, Gauvain ; in the Old French Vulgate cycle she sleeps with her brother, Arthur, and conceives a son, Mordred; and in the Prose Tristan she is murdered by her son, Gaheriet, who finds her in bed with the son of his father's murderer. Read together, these various representations of King Lot's wife describe a woman whose transgressions are consistently linked to her role as mother. An intertextual reading of representations of King Lot's wife in her sons' stories also suggests a profound

\footnotetext{
${ }^{4}$ Le Conte du graal, éd. cit., v. 7590-604.

${ }^{5}$ J.-C. Huchet, « Merceval », Littérature, 40, 1980, p. 94.

${ }^{6}$ On the continuations of the Conte du graal, see Bruckner, «Rewriting Chrétien's Conte $d u$ graal», and «The Poetics of Continuation : From Chrétien's Conte du graal to the Perceval Continuations », French Forum, 18, 1993, p. 133-49.
} 
ambivalence about mothers and the extent to which a son's chivalric identity is defined in relation to his mother's actions. The wife of King Lot seems consistently to threaten her sons in some way, and the narratives never explain why she acts as she does; her motivations and desires remain obscure. This mother appears in stories about her sons, but she has no story of her own.

The wife of King Lot is identified in some texts as "Anna", in others as "Morcadès", but in the Vulgate, the Perlesvaus, and the Prose Tristan, she is not named ${ }^{7}$. Her identity is structural, it is defined by her kinship position : she is sister to a king and the wife of a king, but above all she is a mother. She is consistently identified as the mother of Gauvain and his brothers; however, when her sons are identified with reference to lineage, they are identified as the sons of King Lot. A knight is commonly named as the son of his father in Arthurian romance: Yvain, son of King Urien, is probably one of the best known examples. Knights are not identified through an affiliation with their mothers (nor are daughters) ${ }^{8}$. Fathers enable their sons' pursuit of chivalry, mothers threaten to hinder it. Knowledge and acknowledgement of a relationship to the father seem to be fundamentally important to the definition of chivalric identity, if not to the definition of the romance genre, as Howard Bloch and Emmanuèle Baumgartner have both suggested ${ }^{9}$. Mothers seem much harder to place within romance narratives : what is a mother's story and what kind of identity does it define for her son?

\section{Gauvain's mother}

The thirteenth-century Perlesvaus includes the story of Gauvain's visit, in the company of King Arthur, to a castle where he sees a rich chapel decorated with paintings that illustrate the true story of Gauvain and his birth. It appears that Gauvain was born in this castle, baptized there, and named Gauvain after its lord. He is the son of King Lot, but his mother did not wish his birth to be known, as a priest explains to Gauvain :

Sa mere, qui l'ot dou roi [Lot], ne vout mie qu'il fust seü. Ele le mist en .i. mout bel vaisel, si proia au prodomme de chaiens qu'il le meïst en tel liu qu'il fust periz; e se

\footnotetext{
${ }^{7}$ She is called Anna in Geoffrey of Monmouth's Historia Regum Britanniae and in De ortu Waluuanii nepotis Arturi (Wace follows Geoffrey and also calls her Anna); she is called Morcadés in Les enfances Gauvain, Norcadés in the First Continuation.

${ }^{8}$ Occasionally a knight might be named with reference to his mother, and Galehaut, fils de la Belle Giante, is probably the best example, but the maternal filiation seems to denote some extraordinary attribute of the mother passed to the son. See, for example, Lancelot : roman en prose du XIIIe siècle, éd. A. Micha, Geneva, Droz, 1978-83, t. VIII, p. 74.

${ }^{9}$ R. H. Bloch, Etymologies and Genealogies : A Literary Anthropology of the French Middle Ages, Chicago, University of Chicago Press, 1983, ch. 6 ; E. Baumgartner, «From Lancelot to Galahad: the Stakes of Filiation », éd.W. Kibler, The Lancelot-Grail Cycle: Text and Transformations, Austin, University of Texas Press, 1994, p. 14-30. I have argued elsewhere that the myth of social order represented in chivalric romance is grounded at least in part on the valorization of masculine lineage and the escape from the maternal, ritually enacted through the sacrifice of women. See my «The Poetics of Sacrifice : Allegory and Myth in the Grail Quest », Yale French Studies, 95, 1999, p. 152-68.
} 
il ce ne faisoit, ele le feroit faire a autrui. Icelui chevalier, qui loiaux chevalier estoit, ne vout mie que li chevalier fust periz..$^{10}$

This revelation is recounted without extensive contextualization in the Perlesvaus, and the reader is likely to be as surprised by the story as Gauvain appears to be.

The history of Gauvain's birth may refer to the story recounted in the Enfances Gauvain and other texts, in which Gauvain is born before his parents have married and his mother sends him to be raised in another country ${ }^{11}$. But the Perlesvaus explicitly refutes the idea that Gauvain was an illegitimate child. When the hermit who narrates the story describes Gauvain's mother's abandonment of her son, King Arthur thinks that Gauvain feels shamed by the circumstances of his birth and tries to reassure him by reminding his nephew that he himself was born in similar circumstances: «Beaus niés, fait il, ne soiez pas honteus, car autretel me poez vos bien reprocheir $»^{12}$. Arthur was indeed sent to be raised by a foster family to hide the fact that he was conceived before his parents were married to each other ${ }^{13}$. However, the hermit eliminates any suspicion of Gauvain's birth as illegitimate. When he understands that he is speaking to Gauvain himself, he is quick to reassure him of the legitimacy of both his birth and his baptism : «Sire, vos n'en devez avoir blasme, car vos fustes confermez en la loi que Dex a establie e en la loiauté de mariage dou roi Lot et de vostre mere ${ }^{14}$. The narrator confirms that Gauvain's mother had nothing to hide. Gauvain is identified as the legitimate son of his mother and father, and the narrative includes no explanation of why his mother felt compelled to abandon him, or why she wanted to hide his birth.

Why then did Gauvain's mother abandon him and why did she want to have him killed? These questions do not seem to have any particular importance for the narrative, and the events surrounding Gauvain's birth are recounted in the story with no commentary beyond the hermit's assurance that Gauvain is a legitimate son. In the Perlesvaus, the brief description of Gauvain's birth is a story of abandonment and rescue, and in Arthur's initial assumption of Gauvain's illegitimate birth - that is, that his mother had something to hide - the narrative opens the possibility that

\footnotetext{
${ }^{10}$ Le Haut Livre du Graal, Perlesvaus, Vol. I Texts, Variants, and Glossary, ed. W. A. Nitze and T. A. Jenkins, Chicago, University of Chicago Press, 1932, p. 307.

${ }^{11}$ In Geoffrey of Monmouth's Historia Regum Britanniae, Gauvain is the legitimate son of King Lot and King Uther's daughter Anna. In Les enfances Gauvain and in De ortu Waluuanii nepotis Arturi, Gauvain is illegitimate, born before his parents were married and his birth must be kept secret, but only the Perlesvaus recounts his mother's desire to kill him. See discussion in M. L. Day, ed. and trans., The Rise of Gawain, Nephew of Arthur (De ortu Waluuanii nepotis Arturi), New York, Garland, 1984, p. xxviii-xxix, W. A. Nitze et al, Le Haut Livre du Graal, Perlesvaus, Vol. II Commentary and Notes, Chicago : University of Chicago Press, 1937, p. 327, and P. Meyer, «Les enfances Gauvain : Fragments d'un poème perdu », Romania 39, 1910, p. 1-32.

${ }^{12}$ Perlesvaus, éd. cit., t. I, p. 308.

${ }^{13}$ Keith Busby notes the possibility that «the author has introduced this [episode] to bring Gauvain closer to Arthur, and to stress their attachment to the world ». Gauvain in Old French Literature, Amsterdam, Rodopi, 1980, p. 231.

${ }^{14}$ Perlesvaus, éd. cit., t. I, p. 308.
} 
some prior transgression may have motivated his mother's attempted infanticide. But the text remains silent about the events that could have provoked or explained Gauvain's mother's desire to hide her son's birth and even to kill her son. This mother's story is not told.

That a character in a romance might act in unexplained ways is not unusual, and we would not necessarily expect to see a relatively minor character's motives elaborated in a long narrative like the Perlesvaus. In this episode recounting Gauvain's visit to his birthplace, the knight's apparent lack of curiosity about his mother seems to forestall a narrative development of her motives for hiding his birth. However, when this episode is read alongside others in which this mother appears, the narrative silence about her motivations becomes more apparent.

\section{Mordred's mother}

Although the Perlesvaus emphasizes Gauvain's mother's «loyal marriage » to King Lot, this mother is best known not for her part in producing Gauvain, a paragon of courtly legitimacy, but for her incestuous relationship with her brother, King Arthur, which produced an illegitimate son, Mordred, as recounted in the thirteenth-century Vulgate cycle ${ }^{15}$. When Mordred learns his father's identity from a hermit in the Prose Lancelot, it is under the sign of doom : the hermit announces that Mordred is the most wretched man in the world because he will destroy the glory of the Round Table and kill the bravest man ever known, and this man is also his father. When he hears the hermit's prophecy, Mordred claims that the hermit must be lying because his father is already dead :

Quant Mordrez oit ceste parole, si est moult honteus et dist : " Sire, vos diroiz vostre volenté, mais ce ne puet estre que je jamais occie mon pere, car mes peres est pieça morz. Et por ce que vos dites que je l'ocirrai, ne doit l'an croire chose que vos diez, car vos avez apertement menti de ce que vos avez dit de mon pere. -Comment ? fait li prodom. Dis tu donc que tes peres soit morz? -Oïl, fait il. -Cuides tu, fait li prodom, que li rois Loth d'Orcanie t'engendrast ausi com il fist tes autres freres?» Et Mordrez respont que li rois Loth d'Orcanie l'engendra voirement. -Certes, fait li prodons, no fist, ainz t'engendra uns autres rois qui mielz vaut et qui plus fist de toutes choses que cil ne fist que tu tiens a ton pere. Et la nuit qu'i t'engendra li fu avis a son songe que de lui issoit uns serpenz qui li ardoit toute sa terre et li occioit touz ses homes [...] Et por ce que tu mielz m'en croies, troveras tu el moustier saint Estienne de Camaalot .I. serpent que tes peres i fist peindre por avoir le songe an samblance toz les jorz de sa vie. ${ }^{16}$

\footnotetext{
${ }^{15}$ It has been argued that Mordred's incestuous birth is a late introduction into the Vulgate, invented by the author of La mort le roi Artu and interpolated back into the Lancelot later. (J. D. Bruce, «Mordred's Incestuous Birth», Medieval Studies in Memory of Gertrude Schoepperle Loomis, Geneva : Slatkine, 1974, p. 197-208.) I do not attempt here to define an evolution in the various representations of Gauvain's mother, but rather, to think about the ways in which this character is associated with transgressive maternity in a variety of texts.

${ }^{16}$ Lancelot, éd. cit., t. V, p. 220-21.
} 
The hermit's response to Mordred's objection identifies Arthur's paternity without naming him directly : «another king», not King Lot, engendered Mordred, this king dreamed of a serpent the night Mordred was conceived, this king had the serpent painted in the chapel of Saint Stephen at Camelot. Although Mordred may be able to identify Arthur from this description, he shows no sign of recognition and kills the hermit immediately after he utters his prophecy. Mordred's act of murder fulfills the hermit's prediction of his own death at Mordred's hands, and as a partial fulfillment of the prophecy, it may indicate Mordred's acceptance of the hermit's identification of his paternity as well as of his future patricide in spite of his denials :

Si m'aïst Diex, fait Mordrés, danz viellars, vos nos avez menti d'aucunes choses, et si vos avez dit voir d'aucunes choses, car en ce que vos dites que vos de ma main morroiz ne mentistes vos pas, car vos morroiz orandroit: si avroiz esté devins d'aucunes choses. ${ }^{17}$

The hermit's revelation of Mordred's illegitimate birth does not mention his mother - the point of the hermit's prophecy is that Mordred will destroy his father. But when Lancelot and Mordred leave the scene, Mordred's parents are directly identified for the reader. Lancelot notices a letter in the dead hermit's hand which he secretly retrieves and later reads. This letter, written to Mordred but read by Lancelot, reveals that Mordred's father will kill him :

«Os tu, Mordrez, par cui main je doi morir, saches vraiement que li rois Artus qui t'engendra en la fame le roi Loth d'Orcanie, ne fera mie mains de toi que tu a fet de moi, car se tu me coupas la teste, il te ferra par mi le cors si durement que aprés le cop passera li rais dou souleil ».18

Mordred's mother appears here only briefly, named as the wife of King Lot. The hermit's letter acknowledges the adultery but does not directly name the incest.

Since the hermit's prophecy reveals that the son will kill the father and the father will kill the son, it is not surprising that it does not dwell on Mordred's mother. Moreover, Mordred already knew who his mother was, only his knowledge of his father's identity is challenged by the hermit's prediction. But by naming Mordred's mother along with his father, the hermit's letter inscribes the mother into the genealogy that structures the "war without end $»^{19}$ in which both Arthur and Mordred will die. That is, it identifies the war between Arthur and Mordred recounted at the end of the Vulgate in La mort le roi Artu as a conflict defined by genealogy, and a genealogy in which his mother's identity matters, if only because she is the hidden link between the father and the son.

Although Mordred is associated with incest in some early Arthurian texts, it is only in the Vulgate cycle that he is described as the son of Arthur and his sister. There his birth is attributed to an adultery that is also an unwitting incest : Arthur

\footnotetext{
${ }^{17}$ Ibid., t. V, p. 222.

${ }^{18}$ Ibid., t. V, p. 223.

${ }_{19}$ «la guerre qui jamés ne prendra fin». La mort le roi Artu, éd. J. Frappier, Geneva, Droz, 1965, p. 125.
} 
and his sister are not aware of their relationship as siblings when they conceive Mordred. In fact, Arthur's sister is not even aware that Arthur is not her husband.

Arthur, a squire at this point, falls in love with the wife of King Lot and when he sees the king leave his bed to attend an assembly, he slips into bed with the king's wife.

Et quant il fu couchiés si se tourna et retourna que autre chose n'en osa faire. Et il avint chose que la dame s'esveilla et se tourna devers lui come feme endormie, si quida vraiement que ce fust ses sires, si l'embracha, et quant il fu embraciés si sot bien qu'ele ne se prenoit garde de lui si l'embracha. Et jut o li tout plainnement. Si li fist la dame molt grant joie et bien li fist, car ele quida que ce fust ses sires. Et en tel maniere fu Mordrés engenrés. ${ }^{20}$

King Lot's wife thinks that she makes love to her husband. She does not realize that she is commiting adultery, yet the passage implicates her as the instigator of the act; Arthur does not dare move until she embraces him ${ }^{21}$.

Once Arthur's identity is known and his right to be king is confirmed, Mordred's mother falls in love with him :

Quant ce vint au terme que li enfés fu nés et la nouvele fu par tout le païs que cil seroit rois qui fu fix Uterpandragon, si l'ama la dame molt plus en son cuer que nus nel porroit dire. Ne mais ele n'en osa faire samblant pour le roi Loth son signour et molt li pesa de la guerre qui fu levee entre lui et ciaus del païs. ${ }^{22}$

Mordred's mother falls in love with Arthur at the same time she learns his family identity: that he is her brother. The text does not recount the story in these terms, but in its characterization of the wife of King Lot as a woman who turns to embrace her brother in her husband's bed (even though she thinks he is her husband) and who falls in love with her brother once she knows that they shared a father, the text subtly identifies this mother as blameworthy, as a woman who sought incestuous maternity.

\section{Gaheriet's mother}

A fuller account of this mother's desire is hinted at in the Prose Tristan, where she is murdered by her son, Gaheriet, because she has taken Lamorat de Gales as her lover. Lamorat is the son of Pellinor de Listenois, who killed Gaheriet's father, and Gauvain killed Pellinor in revenge. The enmity between the two clans

${ }^{20}$ Merlin, éd. I. Freire-Nunes, in Le livre $d u$ graal, dir. D. Poirion, Paris, Gallimard, 2001, p. 870 ; See discussion in Bruce, art. cit., p. 207.

${ }^{21}$ The story is represented differently in the Post-Vulgate Merlin Continuation, where Arthur is the actor and the wife of King Lot is completely passive in the narration : « Li rois vit la dame et moult le festia, et li et ses enfans. Li rois vit la dame de grant biauté plainne, si l'ama moult durement et le fist demourer en sa court . II. mois entiers, et tant qu'en chelui terme il gut a li et engenra en li Mordrec, par cui tant grant mal furent puis fait en la terre de Logres set en tout le monde». Here Merlin reveals to Arthur that he has slept with his sister and engendred a son who will kill him. La suite du roman de Merlin, éd. G. Roussineau, Geneva, Droz, 1996, t. I, p. 1-2.

${ }^{22}$ Merlin, op.cit., p. 871. 
endures - Gauvain and his brothers plot to kill Lamorat to pay for his father's act of murder; they also suspect that Lamorat and his brothers may know that Gauvain killed their father and they want to prevent any act of revenge. Gaheriet hates Lamorat for a different reason - because Lamorat shames Gaheriet and his brothers by taking their mother as a lover.

Gaheriet's mother is consistently called the Queen of Orcanie in the story of her liaison with Lamorat, perhaps emphasizing her status as a rich widow. But she is also consistently identified as a mother, and her son Gaheriet is identified as an obstacle to her liaison with Lamorat. Gaheriet has the queen guarded so that Lamorat cannot reach her, and Lamorat complains that Gaheriet kills him without lance or sword when he keeps him from the Queen of Orcanie, as the narrator explains :

Et se aucuns me demandoit ki li cevaliers estoit ki si durement se plaignoit, je diroie que ce estoit Lamorat de Gales, li boins chevaliers, li vaillans, ki si durement s'aloit plaignant pour les amours la roïne d'Orcanie, ki bien estoit a celui tans une des beles dames du monde. Et estoit cele dame mere de monsigneur Gavain et de ses autres freres, et suer le roi Artu. ${ }^{23}$

She is one of the most beautiful women in the world, the mother of Gauvain and his brothers and the sister of King Arthur. Her beauty and status are inseparable from her maternity. It seems that her sons' honor is also inseparable from their mother's actions.

The Prose Tristan recounts that Lamorat wins a great tournament, and Gaheriet is sure that the knight will go to celebrate his victory with his lady. Gaheriet's efforts to guard access to his mother are apparently less successful than previously, since the Queen of Orcanie lives in a castle where she can see Lamorat frequently:

Et en chel castel demouroit mout volentiers la roïne d'Orcanie pour ce que plus estoit pres de Camaalot que nus de ses autres castiaus. Si pooit veoir Lamorat plus souvent et plus de legier que s'il fust $u$ roiaume d'Orcanie. ${ }^{24}$

Gaheriet follows Lamorat to the Queen of Orcanie's castle and discovers Lamorat asleep in his mother's bed. He decides to kill his mother, but not the knight.

Quant Gaheriés voit ceste assamblee s'il est dolans et courechiés, ce ne fait pas a demander. Si les conmenche a regarder la u il dormoient, et il voit que li chevaliers est si biaus et si preus et si hardis com il meïsmes set. S'il ensi l'ocioit, ce seroit la greigneur noiienté et la graindre felonnie, si com il dist, que chevaliers peüst faire com de metre a mort si boin chevalier com chis est, pour tele aventure com est cheste; ne mais de cele voirement ki la honte et la deshounour de ses enfans pourcache si merveilleusement se vengera il a cestui point, si com il dist. Le cevalier ne blasme il point de chestui fait, car il set bien tout chertainnement k'il ne fait a la dame cose nule ki encontre sa volenté soit. Et quant chestui fait plaist a la dame, qui

\footnotetext{
${ }^{23}$ Le roman de Tristan en prose, gén. éd. Ph. Ménard, Geneva, Droz, 1987-97, t. IV, p. 81.

${ }^{24}$ Ibid., t. IV, p. 230-31.
} 
tourne a honte et a deshounour de ses enfans, il est drois qu'ele em port la painne. Le chevalier en laissera il aler tout quitement, si com il dist, et a la dame s'em prendra. Lors met la main a l'espee et dist k'il ochirra sa mere tout orendroit, mais au cevalier il ne touchera, ains l'en laissera aler tout quitement pour la boine chevalerie k'il set en lui. ${ }^{25}$

Presumably Gaheriet's mother "seeks the shame and dishonor of her children" when she sleeps with the son of an enemy ${ }^{26}$, but although Gaheriet repeatedly evokes the shame of the liaison, he never specifically mentions lineage. In fact, the text repeatedly contrasts the enmity of Gauvain and his brothers for Lamorat because he is the son of their father's murderer to Gaheriet's hate for Lamorat because he is his mother's lover. This distinction opens the possibility that Gaheriet's enmity for Lamorat is substantively different from that of his brothers, that is, that Gaheriet sees the shame of the liaison in the mother's pursuit of sexual pleasure. I have argued elsewhere that the execution of the Queen of Orcanie is part of an uneasy tension about maternal sexuality in medieval romance that results in various narrative strategies whose goal is to limit a mother's desire to desire for a child, rather than a lover, as, for example in the representation of Perceval's mother ${ }^{27}$. Here, I would like to read Gaheriet's murder of his mother a little differently, in the context of the various representations of this mother in thirteenth-century romances. What do the stories about King Lot's wife tell us about her and about her own story, which is never fully articulated in any one appearance of the character? What might an intertextual reading of the character suggest about the representation of maternity in relation to chivalry? In other words, how do we make sense of a character who appears as an abandoning mother in one text, an incestuous mother in another, and, in a third, as a mother who takes as her lover the son of her husband's murderer? And perhaps more important, how do we make sense of the lack of explanation for the mother's actions?

It is certainly the case that these representations occur in very different texts that are composed by different authors, and one way to explain these various representations of the character might be to understand Gauvain's mother, Mordred's mother, and Gaheriet's mother as essentially different characters. These characters do in fact participate in stories that do not directly intersect. But Gauvain, Gaheriet, and Mordred are brothers, and their mother is identified as the mother of them all in most of the texts under discussion here, so it does seem that we can read intertextually and that we might ask what this mother's appearances might tell us about the absent mothers who never reappear in their sons' stories once they become knights.

In the brief but repeated appearances of King Lot's wife in thirteenth-century texts, the mother is portrayed as a threat to her sons - she tries to kill her newborn baby, she falls in love with her own brother who is also the father of one of her sons, and she shames her sons through her displays of sexual desire. These appearances of King Lot's wife in different narratives come together as repetitions - as repetitions

\footnotetext{
${ }^{25}$ Ibid., t. IV, p. 231-3.

${ }^{26}$ The Post-Vulgate Merlin also recounts this episode, and in very similar terms.

27 P. McCracken, "Mothers in the Grail Quest: Desire, Pleasure, and Conception», Arthuriana t. 8, no.1, 1998, p. 38-9.
} 
of a narrative ritual of exorcising the mother, of getting her out of the way, of rescuing her sons so that they can become, or continue to be, knights. We know this pattern from Le conte du graal, from the story of Perceval's escape - with the crucial help of the knight Gornemant - from his mother's antichivalric isolation in the wasteland. But it is also suggested in the isolation of Gauvain at the end of Le Conte du graal where the unrecognized son waits for the arrival of Arthur or his knights to witness his battle with Giromelant.

The repeated appearances of Gauvain's mother seem to suggest a narrative pattern that brings the mother back into her sons' stories but always as a character on the margins. The story of her love liaison with Lamorat in the Prose Tristan indirectly articulates something about this character's desires - she lives in the castle of Roche Naïve because she wishes to be near Lamorat - but she never speaks, and the narrative never offers any information about why she acts as she does.

The absence of any indication of this character's motivations for her actions is what allows the shifting representations : the woman joined to King Lot in loyal marriage who later wants to kill her son; the wife ignorant of Arthur's invasion of her marriage bed who initiates their love-making and then falls in love with her brother; the mother of many sons who becomes the lover of her sons' enemy. On the one hand, these transformations of King Lot's wife may not need explanation: they correspond to the medieval misogynist view of women as fickle, unfaithful, disloyal, and governed by their passions. On the other hand, though, while misogynist views of women may influence romance representations, portraits of courtly ladies rarely conform directly to such definitions, so it does not seem that the transformations of the mother of Gauvain and his brothers can simply be dismissed as a misogynist representation. The changing portraits of King Lot's wife - from faithful wife to lover of her brother, for example - call attention to her part in lineage while at the same time identifying her as a threat to its status and value.

E. Baumgartner has suggested that filiation, as a persistent concern of prose romances, may figure textual filiation, the evolution and development of the Arthurian tradition. Focusing on the Old French Vulgate, she argues that the cycle's continuation of a textual chivalric tradition, but with a difference, is figured, for example, in the simultaneous preservation and modification of genealogical models. In other words, the text's representation of lineage may say something about what Baumgartner calls the "perilous dialectic » of Arthurian fiction : «to program an ending, to close the circle[...]by delaying as long as possible the conclusion $»^{28}$.

The expansion of Arthurian romance in prose cycles after Chrétien is an expansion of family histories in which a mother's absence is rendered natural and her presence is problematically linked to a negotiation of her son's chivalric identity in relation to his lineage. Representations of Gauvain's mother further suggest the necessity of excluding the mother from the project of clan loyalty and the protection or guarantee of lineage. Such an exclusion explains the endpoint of this mother's story: Gaheriet's matricide is cast as the ultimate expression of family loyalty. When the Queen of Orcanie's death is known at court, Gaheriet's brothers are in great mourning - they vow to avenge her death, but vengeance seems to be deeply

\footnotetext{
${ }^{28}$ E. Baumgartner, art. cit., p. 29.
} 
linked to regret - not for their mother's death, but for Lamorat's escape. Gauvain laments :

«Dieus, aïe! Ce que puet estre? Conment fu Gaheriés si forsenés k'il laissa aler Lamorat, ki estoit ocoisons de ceste mort, et si le pooit ochirre ausi legierement com chieus ki tous estoit desarmés, et puis l'en laissa si quitement aler, et si savoit vraiement que ce estoit tous li plus morteus anemis que nous eüssiom en cest monde. Par foi, ce fu bien la gregneur forsenerie et la greigneur faute de cuer que chevaliers feïse onques mais. ${ }^{29}$

The knight's greatest fault is not the murder of his mother, but the failure to kill her lover.

The repeated appearances of Gauvain's mother in prose romances after Chrétien suggest a narrative pattern, an intertextual repetition that marks familial and chivalric unity through a displacement of the mother in acts of chivalric and fraternal solidarity. And what the representations of Gauvain's mother seem to add to the story of knights and their mothers is the idea that a mother merits this displacement - even to the extent that matricide can be an act of chivalric worth. More important, an intertextual reading of this mother's appearances in her sons' stories also reveals the extent to which the justification of the sometimes violent exclusion of mothers from the world in which the value of chivalric lineage is negotiated and proven depends on a silencing of the mother's own story.

Peggy McCracken

University of Michigan, Ann Arbor

${ }^{29}$ Le roman de Tristan en prose, éd. cit., t. IV, p. 235. 